\title{
MS PARIS, BIBLIOTHĖQUE DES MisSIONS ÉTRANGÈRES 1069: THE FRENCH-ARABIC DICTIONARY OF FRANÇOIS PETIS DE LA CROIX (1653-1713)?
}

\author{
SONJA BRENTJES \\ MAX PlanCK INSTITUTE FOR THE HisTORY OF SCIENCE
}

\begin{abstract}
This paper analyses an anonymous French-Arabic dictionary preserved in Paris, Bibliothèque des Missions étrangères. I argue that it seems to be a copy of a dictionary compiled by the early modern French Orientalist and diplomat François Pétis de la Croix, the younger. Beyond the question of authorship, I survey the themes and structure of the dictionary and discuss the compiler's cultural insights into Ottoman and Safavid societies and the cultural barriers that his translations reveal.
\end{abstract}

\section{Key Words}

Study of Arabic in Early Modern France, Travelers in the Middle East, History of Knowledge.

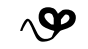

Dictionaries, grammars and conversation books were important tools in the seventeenth century for cross-cultural contacts. Many of them, whether complete or merely fragmentary, are preserved, but rarely studied, although they provide insights into the expectations and skills of the compilers to engage directly with a person of another culture. The vocabulary and phrases found in those sources document the scope and character of the topics about which a compiler wished to talk or write. They illustrate his education, his beliefs and his knowledge of foreign languages. Many of the works assembled by missionaries, merchants, interpreters, scholars or gentlemen travelers from France, Italy, England, German principalities or the Low Countries do not contain more than a few hundred words, rudimentary elements of grammar or a small set of phrases. Their main themes are religion, aspects of daily life, desires to interact with women and some basic knowledge of arithmetic, astronomy, geometry or geography.

A minority of dictionaries and grammars, in particular, was more fulsome and included several hundreds of words or described the main components of Arabic, Persian or Turkish grammar, often following the standards of Latin grammar 
books. Exceptional examples of dictionaries also exist, which can cover several ten thousand words plus at times a series of phrases. Such an exceptional dictionary is the object, which I will discuss in this paper. It is the big French-Arabic dictionary MS 1069, owned by the library of the Missions étrangères in Paris. It contains 1905 pages. Neither its date nor its author is known. MS 1069 is the only so far known version of this large collection of words and phrases with the specifics that characterize them. No other known French-Arabic dictionary from the seventeenth and early eighteenth centuries resembles it. Hence, all interpretations offered in this paper are based on this single, anonymous manuscript.

My paper surveys the content of the dictionary and highlights some of the cultural achievements made by its compiler as well as some of the cultural obstacles, which he did not manage to overcome. In the first section, I offer arguments for the time of compilation and a proposal for who the compiler of the long list of words and expressions may have been. The second section supports my proposal regarding the compiler by information taken mainly from the diary of this man. The third section discusses the dictionary's structure and formal properties. Sections four to six analyze the content of the dictionary according to its major word clusters: Muslim education and cultures; religious matters; politics, navigation, crafts and commerce. Section seven surveys examples expressing the cultural boundaries with which the compiler struggled and how he dealt with them. Section eight summarizes the results and highlights the main insights into a prime example of an early modern dictionary of two languages of essential relevance to politics, trade and culture.

\section{Time of Composition and Possible Authorship}

The Missions étrangères were founded in Paris between 1658 and 1663 and run since 1659 by the Propaganda Fide in Rome. This sets a lower limit for the acquisition of the dictionary.

No further information about the origin of the work is available in the library of the Missions. Hence, the only available source for reflecting about when this project has been carried out and who might have composed it is the dictionary's content. This content provides clear information about the time span during which the collection was finalized. The repeated references to Louis XIV as a child and then the ruling king of France limits its production to the period between 1643 and $1715 .{ }^{1}$ The search for the historical origin of key words in MS 1069 in the database built for the Dictionnaire de l'Académie Française documents the existence

$1 \quad$ MS 1069, p. 115, 264, 1002, 1490, 1580, 1685. 
of a number of terms from the seventeenth century. ${ }^{2}$ This confirms that the work compiling this large set of words was carried out in the second half of the seventeenth or at the latest in the early eighteenth centuries.

These results do not prove, however, that the version extant today in the library of the Missions étrangères is the version written or dictated by its compiler. MS 1069 contains a few elements that suggest its being a copy of an earlier version. One of those elements is the contradiction between the French and the Arabic terms in a single line. Examples are Alexis and rashā (spelled in this manner) or Allidade (spelled in this manner) and Ya'qūb, Dalīla. ${ }^{3}$ Alexis is an ancient Greek male personal name; rasha as spelled and vocalized in the dictionary, can either be read as the verb rasha or the noun rish $\bar{a}$, none of which represents a personal name. Neither are the two words semantically related to Alexis, since Alexis seems to be derived from aléxō to ward off, turn away, defend etc., while rashā and rish $\bar{a}^{\prime}$ mean very different things, among them to bribe or to conciliate someone with something, the rope of a bucket or a lunar mansion. ${ }^{4}$ Allidade, being a mispelled medieval tranliteration of al-idāada, a kind of ruler attached to an astrolabe, some other instrument or functioning itself as such, is clearly not related to the ancient lovers Jacob and Delila. Such mistakes point to a loss of at least one, if not more lines during copying. ${ }^{5}$

A second indicator that MS 1069 is a copy of an earlier version is the existence of elementary scribal mistakes in comparison to correctly written related words. An example is the absence of the alif as a carrier of a kisra (a short i) in front of țāliyānī, which orresponds to Italien. ${ }^{6}$ In the line above, Italie is properly transcibed with such an alif as itâliya. Other examples of this type are the vocalization of madrasatun with a sign for the absence of a vowel (sukūn) not only on the dāl (d), but also on the mim (m), the vocalization of bi-'awn (illahhi wa-tawfiqihi) with two dammas (short $\mathrm{u}$ ) instead of one damma and one sukūn, the mispelling of daftarun as waftarun, the replacement of $y \bar{a}$ (a long i) in ta' rif by a kisra, the spelling of $y a^{\prime} d u b u$ with a waw (a long $\mathrm{u}$ ) instead of a damma (ya'dūbu), the confused rendering of perspective as 'ilm al-manțūrāt instead of 'ilm al-manzūuāat or more appropriately 'ilm

\footnotetext{
See, for instance, the following entries at < https://www.dictionnaire-academie.fr > (last accessed 17 March 2021): canicule (for Sirius); censure; propagande; dissertation; exactitude; laboratoire; libertinage; pléonasme; rafinement (sic!); salon (MS 1069, p. 198, 219, 322, 522, 658, 957, $982,1301,1438,1593)$.

$3 \quad$ MS 1069, p. 36, 39.

4 < http://www.perseus.tufts.edu/hopper/morph?l=a\%29le\%2Fcew\&la=greek\#lexicon > (last accessed 17 March 2021); EdWARd William LANE, An Arabic-English Lexicon, 8 parts, Librairie du Liban, Beirut 1968, pt. III, 1001.

$5 \quad$ MS 1069, p. 103.

6 Ibid., p. 948.
} 
al-manāzir or the presentation of the Arabic translations for jardin potager and potage in a wrong order. ${ }^{7}$

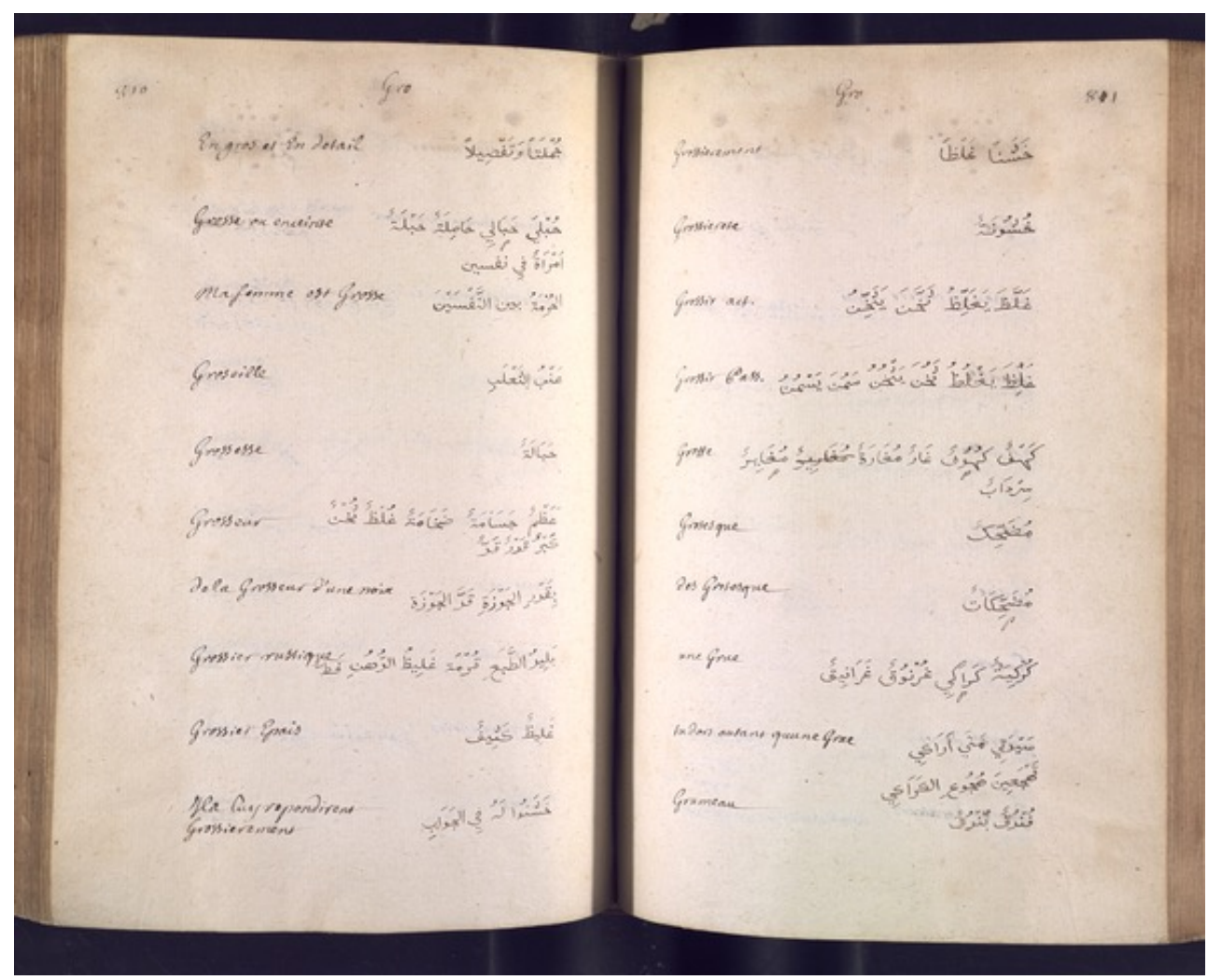

Fig. 1. MS 1069, p. 800-801. ( Institut de recherche France-Asie/MEP

A third element identifying MS 1069 as a copy are a few instances where a word or more were crossed out. A particularly forceful example is the crossing out of the Persian word hindūwānah (water melon) on page 1048 for membrane followed by jildun rakikun, because it appears in its proper place in the previous line as one of three translations of melon d'eau.

In addition to entries pointing to a copyist at work there are also entries that document the involvement of more than one person in MS 1069. Such entries appear in visibly different handwritings, often also the usage of a differently colored ink and at times in references to other pages, which do not agree with the content of the corresponding page numbers in MS 1069. One such case appears, for

Ibid., p. 5, 27, 59, 75, 443, 1257, 1332, 1344. 
instance, in the transliteration of numerals on page 220. The person who was responsible for this transliteration used spoken, not literary Arabic such as tlatamya instead of thaläthami'a. Another case is the addition of the words Lievre with its Arabic correspondances arnab, arānib and Abūl-Hasan on page 986 and Livre for kitāb, kutub and safr (sic) on page 993. Both examples are written by at least one different hand with a different ink. The first example refers the entry to page 980 and the second to pages 981 and 982 . These entries probably refer to a second dictionary from which the lemmata were added. While this second dictionary can of course have been the work of some other compiler I think it is more likely that the additional entries were taken from an oldr version of the dictionary extant in MS 1069. The page numbers provide a justification of why they were added and a specification of where they were found in this older version. Hence, the person who provided those references participated most likely as a proofreader of MS 1069.

As for the collection's composer two elements in the manuscript of the Missions étrangères provide suggestions. One is the appearance of two more names on its pages. The other are some of the specifics of its content with regard to lexic and information about Muslim education and intellectual traditions. The two names are "monsieur du bois» and "monsieur de la Croix», following one after the other as illustrations of the lemma « monsieur $»{ }^{8}$ The first refers in all likelihood to Philippe Goibaut Sr. Du Bois La Grugère (1626-1694). ${ }^{9}$

The rich and comprehensive content of MS 1069, which I will discuss in the following sections, differs clearly from most other French-Arabic dictionaries of the period that I have seen. The strongly worldly character of many of its topics sets it apart from dictionaries compiled by missionaries. This makes it implausible to consider missionaries like Bernard de St. Thérèse (1597-1669), one of the founders of the Missions étrangères, as possible authors. The mix of vocabulary and the intimate familiarity with matters of Islamic education and scholarship point vocally to another group of French men, who produced French (or Latin) dictionaries of Arabic, Persian, Turkish and other languages in the early modern period - the secretaries and translators of the French embassy in Istanbul and later language professors, court translators and officials in other positions in Paris. For the second half of the seventeenth and the first decade of the eighteenth centuries only two members of this group appear as likely candidates for the ancestor of MS 1069 - the colleagues and friends François Pétis de la Croix (the younger) (16531713) and Antoine Galland (1646-1715). ${ }^{10}$ I have six reasons to opt for the first of

Ibid., p. 1084.

Ibid.

10 In order to accept this proposal, one has to know many of the other early modern dictionaries involving western European languages on the one hand or Arabic, Persian or Turkish on the other. Such a large comparative study is beyond the scope of this paper. But having seen 
the two: the intimate knowledge of Muslim educational, intellectual and religious terms, an indirect reference to the Shāhnāma, a direct reference to features of Iranian landscape and geography, an entry stating that someone was a natif of Paris (wa-Bärīs mawaladuhu [sic]), clear spelling differences in French between MS 1069 and the journals of Antoine Galland and several lexical and interpretive agreements between the Arabic-Latin dictionary compiled and written by Pétis de la Croix. ${ }^{11}$ Further support for this suggestion can be found in Pétis de la Croix's description of his physical and educational journeys in the Ottoman and Safavid Empires during ten years of his life, which I will summarize in the following section.

\section{Who Was François Pétis de la Croix (the Younger)?}

François Pétis de la Croix (the younger) was the son of the Arabic interpreter of Louis XIV, François Pétis de la Croix (1622-1695). In 1695, he inherited his father's office and became the most successful diplomatic mediator of the French crown in North Africa (1681-1687). He had substantially improved his knowledge of languages (Arabic, Turkish, Persian), whose study he had already begun with his father, and acquired his knowledge of social customs and codes during 10 years of travels and studies in the Ottoman and Safavid Empires, with long sojourns in Aleppo (1670-1674), Isfahan (1674-1676) and Istanbul (1676-1680). As manuscripts in the Bibliothèque nationale de France show, part of Pétis de la Croix's training in Aleppo consisted in correcting, annotating and translating Arabic scholarly texts. ${ }^{12}$ He wrote about this phase of his training:

I arrived in Aleppo November 19, 1670. The first thing I did there was to find three teachers. I took one for teaching me the vernacular. He knew a little Latin. The second whom I hired was for the literary Arabic. He knew no European language, but he was a very gifted man in the Oriental erudition. The third one showed me the Arabic script, which one calls naskhì. As soon as I spoke that language, I dismissed the first teacher. In his place, I took a mullah to teach me poetry. I took the service of these three people as long as I was in that town. But after a while I hired a fourth teacher to begin learning Turkish, which one spoke in Persia, and six months later a fifth one for the music of the Arabs to execute as much as possible according to the order that I had received to penetrate this science as much as possible in the manner in which one knew it in the Levant. [...] Finally, after having read and

numerous French, Italian, Latin and German works of this kind I strongly believe that my identification of François Pétis de la Croix as the ultimate author of the ancestor of the manuscript I discuss in this paper is as solid as possibly can be.

11 MS 1069, p. 449, 1085 or 6 (the pagination was changed), 1113. The entry of having been a natif of Paris only applies to Pétis de la Croix, because Galland was born in Rollot. See MS Paris, BnF, Arabe 4343.

12 MS Paris, BnF, Arabe 1683; perhaps also MS Paris, BnF, Arabe 1473. 
studied 38 volumes of books in Arabic about history, geography, geometry, arithmetic, philosophy, poetry, chancellary letter-writing, books on religion, the Qur'ān and others, and several in Syriac and karshūnī, seeing nothing more in prose and verse, which I could learn in Aleppo, I prepared myself to go to Persia according to the order, which I had in my instructions. ${ }^{13}$

On his way to Isfahan, he met scholars in several towns, who invited him to discuss with them poetry and theology. He stayed in Shiraz for five days, because he wished to visit the city's schools of higher education. He found that one taught poetry, theology, "occult philosophy ", mathematics and law there. ${ }^{14}$ After his arrival in Isfahan, he presented himself first to Raphael du Mans, the head of the Capuchin house in Iran, on order of his French superiors. Du Mans taught him the basics of Persian. ${ }^{15}$ It took Pétis de la Croix some time to find a suitable local teacher who spoke Arabic well. He reports with pride that he and his teacher worked so hard that after six months he spoke " an elegant Persian », i.e. a highly Arabicized literary language. ${ }^{16}$

Once being able to converse with the Muslim elite, he took a Zoroastrian as a second teacher, who knew no Arabic and learned from him not only spoken New Persian, but also Middle Persian. Then he turned to further Iranian languages and New Persian dialects. ${ }^{17}$ Six months of studying the Shāhnāmeh with some Mullah Karim followed. Then he hired a knowlegeable person linked to the Safavid court to learn the intricacies of the courtly language and behavior, both of which he found extremely difficult to master. At the end, he wished to study theological matters in verse form (mathnavi), but could not find a teacher for the money he offered. He turned to the madrasas and won the head of the Mavlavī order in town to take him as a disciple for about five months. In addition to these one-to-one classes, Pétis de la Croix entered quickly into relations with men of the Safavid family, helped by Raphael du Mans, who invited him not only for recitations of poetry, but to all the lectures Isfahan's leading scholars gave to them. ${ }^{18}$ The last language he studied with a native speaker in Isfahan was Tatar, which probably meant Chaghatay Turkish or Uzbek, but without reaching a higher level. ${ }^{19}$ Over five more pages, Pétis de la Croix then describes what else he did in Isfahan on order of the French court and its minister Colbert. In a short manner one could say

13 François Pétis de la CRoIX, « Extraits du Journal du Sieur Fr. Petits fils, professeur en arabe, ... », ed. M. LANGLÈs, Magasin encyclopédique ou Journal des Sciences, des Lettres et des Arts, 5 (1808), p. 281-282, 290.

14 Ibid., p. 317-318.

15 Ibid., p. 320.

Ibid., p. 321.

Ibid., p. 322-323.

Ibid., p. 324-327.

19 Ibid., p. 329. 
his task consisted in a fully exhaustive description of everything and everyone which or who was found in Isfahan: the buildings, gardens, scholars, artisans, the royal family, the different religious communities, the arts and the sciences, the animals and plants, the produce of agriculture, books and paintings as well as any other thing or person to be found in or around town. ${ }^{20}$ The dictionary I discuss here reflects this broadness of matters, themes and people to a large degree. This is a major argument for Pétis de la Croix's authorship and a feature that sets this work apart from its contemporaries.

In the Ottoman capital, Pétis de la Croix served as secretary for the French ambassadors Charles Marie François Olier, Marquis de Nointel (1635-1685; ambassador in Istanbul from 1670-1679), for whom he translated a great number of letters exchanged between the two courts as proof for his philological competence, and Gabriel-Joseph de Lavergne, Comte de Guilleragues (1628-1684; ambassador in Istanbul from 1679-1684). After his return to Paris, he engaged in translating various Arabic, Persian and Turkish historical and literary works as well as diplomatic messages and reports. He learned Armenian and Amharic. In 1692, Pétis de la Croix was appointed professor of Arabic at the Collège Royal in addition to his courtly office. ${ }^{21}$ In this period, he not only continued to translate, among other items the substantial, bibliographical encyclopedia Kashf al-zunūn, of Hajji Khalīfa (d. 1657), but to compose dictionaries for Arabic, Turkish, Persian and Armenian in French or Latin as well as an Arabic grammar and some exercise collections. A list of publications and unpublished works was compiled by Sebag. ${ }^{22}$ Unfortunately, Sebag did not provide information on the libraries, which hold the manuscripts or the manuscripts's sigla. He might have merely taken this information from the supplement to Moreri's 18th-century historical, genealogical and geographical dictionary ${ }^{23}$ Hence, it is impossible to say whether the FrenchArabic dictionary listed by the two authors might be (or has been) the ancestor of the one that I discuss. ${ }^{24}$

The analysis of the content of MS 1069 that follows now will further support my proposal that the dictionary's compiler was most likely François Pétis de la Croix

$20 \quad$ Ibid., 330-335.

21 For an anlysis of his teaching program see PierRe AgERon, MustaPHA JAOUHARI, « Le programme pédagogique d'un arabisant du Collège royal, François Pétis de La Croix (1653-1713) », Arabica, 61 (2014), p. 396-453.

22 PAul SeBAG, «Sur deux orientalistes français du XVIIe siècle: F. Petis de la Croix et le sieur de la Croix », Revue de l'occident musulman et de la Méditerranée, 25 (1978), p. 97-101. A document of Pértis de la Croix's works compiled in the eighteenth century was recently published BY TSETSUO NisHio, « Un document inédit à propos des ouvrages de François Pétis de la Croix (1653-1713) », Bulletin of the National Museum of Ethnology, 42/4 (2018), 411-433.

23 LOUIS MORERI, Supplement au grand dictionnaire historique, genealogique, geographique, \&c., vol. II, La Veuve Lemercier et. al., Paris 1732, Letter P, p. 47.

24 SEBAG, « Sur deux orientalistes français », p. 98. 
(the younger). Pétis de la Croix left Istanbul in 1680 for Paris. While he had perhaps started collecting data for his later works during his time in the Ottoman and Safavid Empires, the substantial work of compiling such a long dictionary may rather have taken place in Paris between 1692 and 1713 during his professorship.

\section{Structure and Formal Properties of MS Paris, M.E. 1069}

The dictionary is organized according to the French alphabet, presenting nouns and verbs with a first capital letter and verbs in the infinitive. ${ }^{25}$ I follow the French spelling of the early modern source and avoid modernizing it according to today's standards. Since occasionally, the spelling in the dictionary differs from other early modern forms of spelling, I indicate such differences by adding (sic). In the case of Arabic, Persian or Turkish, I provide the spelling of the dictionary when given. Otherwise I follow the rules of classical Arabic grammar and Steingass's Comprehensive Persian-English Dictionary.

The Arabic presents verbs in the third person singular first for the perfect and then for the imperfect. Numerous nouns appear in the singular and the plural, but not always. Repeatedly, more than one plural form is given. This feature may not only reflect the good grammatical training that the dictionary's author had received, but may also point to his usage of one of the famous Arabic dictionaries and/or grammars. The French is at times complemented by Latin words or expressions (see, for instance: caporal [fr.], decurio [lat.]), while some of the Arabic terms are also translated into Persian (murabba', jār kūshah), complemented by Turkish words or are simply transliterations of Italian words (antūn; tak; būṣulah; qātūlìqī; bulūkbāshī; qunșul; ghalyūn, karmalìtān). ${ }^{26}$ The transliterated words are mostly terms for specific missionary orders, Christian names, some military, navigational or commercial terms like the gallion (ghalyūn), the magnetic compass (būsulah) or the consul (qunșul). The presence of Turkish translations such as bulūkbāshī (bölükbaşı, squadron's head) may indicate that no Arabic terms had been coined or that for those concepts only Turkish words were used when speaking or writing Arabic. ${ }^{27}$

25 One of the reviewers asked which dictionary would not be organized in such a manner but also wished to know whether it was organized thematically. The answer is no in both points. I know dictionaries of different kinds of structure, even if they are organized alphabetically as the one, I discuss here. See, for an example, SonjA BRENTJES, «MS or. fol. 100. Adam Olearius' and Haq Virdī's (c. 1584-1650) Persian-Latin Dictionary », in KiRsten Baumann, Constanze Köster, Uta KuHl (eds.), Adam Olearius - Neugier als Methode. Tagungsband zur Internationalen Tagung 'Der Gottorfer Hofgelehrte Adam Olearius. Neugier als Methode?' Schloss Gottorf, Schleswig, 24-27. Juni 2015, Michael Imhof, Petersberg 2017, p. 144-151.

26 The vocalization given here and in further examples below is that of the dictionary.

27 MS 1069, p. 57, 87, 201, 205-6, 212, 287, 335, 769. 
In addition to simple nouns and verbs, the dictionary contains numerous compounds and phrases. The latter are not ordered according to the letter of the first word of either of the two, but a word determining the content of the French compound or phrase. Simple examples are Dieu aidant and Pierre d'aigle, which both appear under the letter $\mathrm{A} .^{28}$ The reader of the French words is often helped by some explanatory note such as Air Element, which is often missing on the Arabic side. ${ }^{29}$ In cases, where a French word has different meanings or different spellings, a cross reference is provided. Examples are agacer v. irriter or annoblir v. ennoblir. ${ }^{30}$ Synonyms are often, albeit not always, given in both languages (in various cases the vocalization is, however, faulty). Examples are avancement, progress $s^{31}=$ taraqqi, sabaq (sic), izdibād, iqbāl; avancer, étendre = murra, yamurru; avancer, proposer = dhakara, yadhkuru mas'ala; cabale (sic), ligne, intrigue = ittifāq, ta' ähud; citation = isnād, asādìd (sic); shahāda, shawāhid; istishhād; definir = 'arrafa, yu'arrifu; wașafa, yașifu; hadda, yahiddu..$^{32}$ While many cases consist of one word only, there are also many instances were word clusters are given. Most often, such clusters consist of a substantive and an adjective or a substantive, a verb and a nomen agentis like Armenien and Armenie or argument, argumenter and argumenteur..$^{33}$ Other cases encompass several nouns or present words of similar content. Such clusters sometimes also include phrases. Examples are argent, argent monoié, je n'ai point d'argent, argent vif, argenté; arpent, arpenter, arpentage, arpenteur, instrument pour arpenter or artifice, artificiel, artificieusement, artificeux, feu d'artifice and user d'artifice. ${ }^{34}$ Occasionally, such clusters appear at the wrong position of the alphabet such as art, artisan, les artisans, artisan mechanique, habile artisan, of which one word, namely artisan, later appears at the appropriate position. ${ }^{35}$ These clusters may imply that the author may have combined here traditions of French dictionaries with those of Arabic dictionaries.

Many Arabic words are fully vocalized, but not all words are translated. The vocalization often seems to reflect a spoken Arabic. This holds true in particular for the frequent use of damma instead of kisra or fatha (a short a). The presence of some rarely used signs in the vocalization of Arabic compounds highlight the excellent knowledge of classical written Arabic of the dictionary's author. An example is the wasla $i$, which signals the so-called weak hamza. Its use in the dictionary is restricted to approximately the first thirty pages. ${ }^{36}$

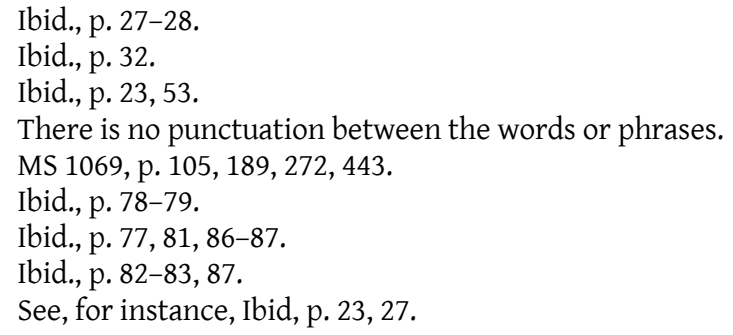


Beyond the described structural properties of this dictionary a few formal characteristics should be listed. The manuscript is paginated with Arabo-Indian numbers in western European format. Not being a codicologist, I did not reflect on the script of the numbers and thus cannot vouch for the time of pagination. Neither can I give any information on the type of paper, cover or binding. Most of the dictionary is written in the same hand. But as already stated above, other hands, using different inks, can also be found.

\section{The Thematics Breadth of MS 1069}

A dictionary of 1905 pages contains of course many lemmata. Thus, it can be expected that a broad array of themes is covered by them. A comprehensive analysis needs to be done once the work is digitized. The summary I provide here is offered as a starting point. In a highly aggregate form, the topics can be described as covering politics and diplomacy, religions, the sciences, Muslim education, nature, commerce, piracy, architecture, geography, health, food, war and luxury. A lower aggregation brings out a detailed vocabulary for plants, spices, animals, metals, Muslim education, astronomy/astrology, piracy and navigation, politics, geography and weaponry. Diplomacy and religion come in as a second close. Among the less often served themes we find sweets, cloths, behaviorial values, women, jewelry, colors, the crafts, titles and offices.

The vocabulary of the anonymous dictionary shows its compiler in more than one function. He certainly worked with Arabic books, integrated words and expressions learned from his teachers, showed himself aware of Turkish geographical, military and other terminology, which he added to Arabic terms or used instead of an older Arabic terminology, and appears clearly as a translator. The first function comes to the fore whith regard to the many birds and other animals found in the dictionary like milan, pan, pelican, pincon or plongeon. ${ }^{37}$ This set of words supports the suggestion of Pétis de la Croix's authorship, since he also translated Kamāl al-Dīn al-Damīrī's (1344-1405) Kitāb al-hayawān (The Book of the Animals) into French. Another group of words and expressions, which reflect de la Croix's learning experience, concern scientific, medical, philosophical, grammatical and religious terms. Examples are dieu aidant, ame intellectuelle, ame sensible, les attributs de Dieu, cancer maison du zodiaque, chirurgie, colique, l'eloquence science, ephemerides, epilepsie, fievre quotidienne, les etoiles fixes, frenesie, les intelligences et les ames celestes, letre ponctuée, letre sans point, le monde intelligible, les mathematiques, le $1^{e}$ mobile, mouvant mobilis, des notes marginales, object de science, octave en musique, or opposition en astrologie..$^{38}$ In contrast to the examples below,

37 Ibid., p. 1068, 1189, 1236, 1282, 1304.

38 Ibid., p. 27, 44, 103, 197, 260, 284, 574, 625, 709, 716, 751, 923, 976, 1020, 1075, 1101, 1132, 1140, 1151, 1164. 
which show de la Croix as translator, these words and expressions are paired with terms used by Muslim and to a lesser extent Christian subjects in the Ottoman and/or the Safavid Empires.

The second domain of words listed above is reflected by the many terms for scholarly disciplines of the canon of higher education in Islamicate societies or for expressions related to studying, learning or teaching in forms characteristic of Muslim educational language. Pétis de la Croix lists not merely simple words like apprendre, enseigner, faire savoir or leçon, faire leçon, cours des etudes, classe école or instruction, but offers simple sentences or sayings characteristic for the world of the madrasa. ${ }^{39}$ Among the numerous sentences and phrases related to study and education we find: "Il falloit etudier nos leçon », "les viles ou j'ai etudié », " apprendre la science sous quelquun», "commentaire avec citations", "se distinguer en une science ", «J'étudie de peur d'etre blamé », « tous les savants lui cedent en science », «Ibn Isaac est de ceux qui ont condamné la chimie », or " Je suis tout prest d'etudier $\gg .^{40}$

The author's familiarity with Turkish terminology is represented by the use of namsah (namshah?) for Germany, majär for Hungary, bilād al-filamink for the Low Countries or leh for Poland. ${ }^{41}$ Other geographical terms confirm his familiarity with Arabic geographical literature. He translated for instance Esclavonie as well as Moscovie with the literary term bilād al-șaqāliba (the Land of the Slavs) or Pont Euxin with the typical misplacement of diacritical signs in Arabic (Persian or Ottoman Turkish) texts as bahr nițūs instead of bahr bunțūs. ${ }^{42}$

The function of translator appears when religious, scholarly or political concepts, traditions, rulers or forms of governance are transferred from a Catholic or French context into Arabic and more rarely from a Muslim context into French. The scholarly vocabulary includes history, medicine, mathematics and other sciences, philosophy and theology. Examples are words like anatomie, apoplexie, arc en ciel, les regles d'arithmetique, atome, axiom, capricorne, cosmographie, Darius, epiphanie, mouvement circulaire, le moteur de l'univers, la mécanique or vicaire. ${ }^{43}$ The French political and administrative vocabulary that Pétis de la Croix wished to provide Arabic expressions for includes words like ambassadeur, Votre M.té toujours auguste, citoyen and citoyenne, magistrat, lis pour les voleurs, maire de ville or parlement. Their identifications as wāfid, wufūd and marsūl, hadaratuka al-jalīla wa-sa'ādatuka al-'āliyya, baladī and hadarì plus their respective feminine forms, shaykh, țumghat (instead of tamghat) âl-sultān, mutawallì (instead of mutawallin) and al-dìwān al-'ālì I

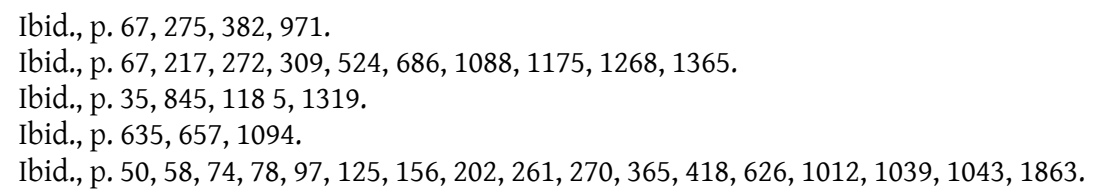


will discuss in section six. ${ }^{44}$ These and other words highlight Pétis de la Croix's serious wish to enable a conversation about structural aspects of the French kingdom as well as its system of punishment.

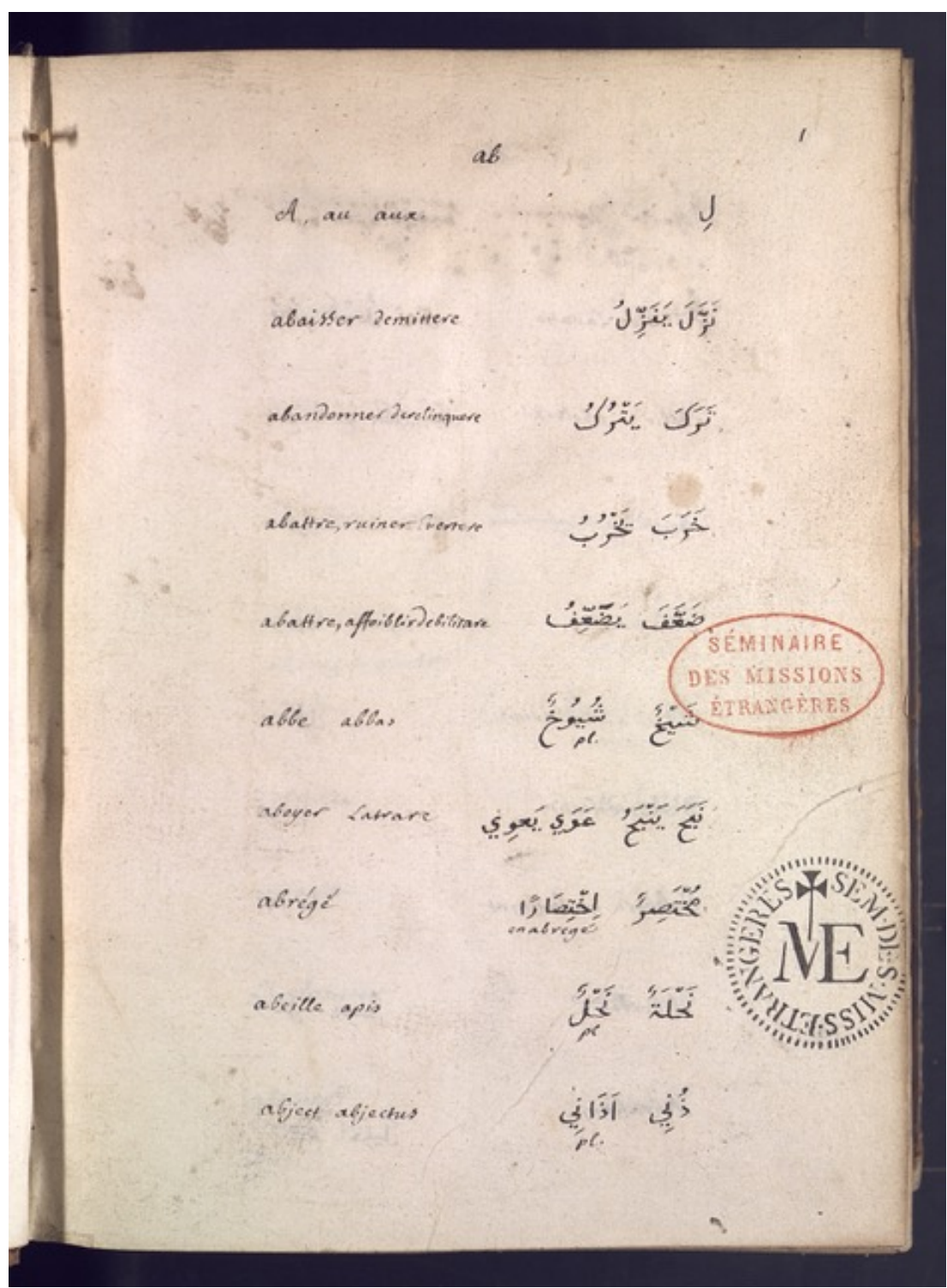

Fig. 2. MS 1069, p. 1, ( Institut de recherche France-Asie/MEP.

${ }_{44} \quad$ Ibid., p. 43, 115, 273, 1010, 1016, 1238. 


\section{Insights into Muslim Higher Education and Cultures}

In the late seventeenth century, Muslim higher education in the Ottoman Empire took mainly place in two institutional contexts: the madrasa and the palace school. The latter was not directly accessible to Pétis de la Croix. A further institutionalized context of intellectual training was the Sufi lodge. A person who wished to acquire the knowledge taught at madrasas or Sufi lodges did not have to formally inscribe in any of them. He also could hire a private teacher from these milieus. The Muslim educational landscape of Safavid Iran resembled that of their western neighbors with the difference that the law and the hadith taught there was that of the 12-Shî community. The madrasa organization was not bureaucratized to the same degree nor do we have clear information about a palatial school for the Georgian military slaves. Pétis de la Croix mostly learned with private teachers. He studied Arabic and Persian with them and Ottoman and Chagatay Turkish. His travel account leaves no doubt that he read the Qur'ān and various exegetical works, was introduced into the world of Sufism and studied historical, geographical, mathematical and literary works. His dictionary suggests that he also received some information about the disciplines of ușūl al-din (foundations of faith), 'ilm al-bayān (rhetoric), the four main philosophical sciences of logic, metaphysics, natural philosophy and ethics taught at Ottoman and Safavid madāris at the very least in form of texts on the classification of the sciences, medicine, astronomy, astrology, music and some of the so-called occult disciplines like physiognomy and chiromanty as well as basic divinatory practices such as fäl.

Although the vocabulary in his dictionary would not have enabled any of its students to engage in a more profound discussion on any subject of those disciplines, it is much richer than any comparable dictionary produced by a Catholic or Protestant visitor of either of the two Muslim countries. It does not merely list the most elementary terms, but goes in some fields substantially farther. This is particularly true for astronomy and medicine. In many cases, it relies on terms used by scholars and reflects the language of educational and other texts. The other early modern Arabic, Persian or Turkish dictionaries compiled by a traveler from Europe that I have explored reflect the daily-life language of Christian minorities and differ significantly from the standard language of Muslim scholarly practices.

Biographical dictionaries from the Ottoman Empire provide access to structure, canon and themes of madrasa education in the major cities. Muhammad alMuhibbī's (d. 1699) Tārīkh khulāșat al-athar fì a'yān al-qarn al-hādì 'ashar (The History of the Quintessential Trace on the Eminent Men of the Eleventh Century), for instance, lists the so-called traditional sciences (al-ulüm al-naqliyya), which include the reading of the Qur'àn, its exegesis, the sayings of the Prophet and his companions, Islamic law in three of its four main Sunni schools (shafi $\overline{1}$, hanafī, hanbalì), the so-called rational sciences (al-ulüm al-aqliyya), which encompass the 
two disciplines that teach the foundations of faith or law, philosophical subjects, medicine, for some authors also the philological disciplines and occasionally astrology, alchemy and parts of magic, and finally the mathematical sciences (al'ulüm al-riyādiyya) with geometry and mensuration, arithmetic, algebra, number theory and magic squares, astronomy and theoretical music (al-Muhibbi 1284/1867). Manuscripts indicate that within the cluster of the philological disciplines of grammar, declination or semantics, but often not specifically listed in Ottoman biographical dictionaries as subjects of study, the earlier disciplines of $a d a b$ also had their place. Pétis de la Croix's dictionary reflects this component too as it provides its readers with words, expressions and phrases from the rational and the mathematical sciences. ${ }^{45}$

Educational institutions appear regularly. Most of them are correctly identified in Arabic, but not all of them correspond precisely to the French original. In most of those cases, this reflects the existence of cultural boundaries, which I will discuss in section six. In contrast to many of his traveling contemporaries, Pétis de la Croix knew that there existed two types of schools: kuttāb and madrasa. ${ }^{46} \mathrm{He}$ identifies them as classe or école, without explaining their difference, the first being for children acquiring elementary education, the second for adolescents and adults who had progressed to the higher stage of learning. On a later occasion, he translates college as madrasa, madāris, indicating therewith his understanding of the level of education provided there ${ }^{47}$ Afterwards, he identifies the students at the kuttāb as children, although this is limited to the Arabic translations where the word escolier is used (awlād al-kuttāb). ${ }^{48}$

It should be highlighted that often, although not always, the French part of the dictionary lists feminine forms for nomina. This applies also to students. The French feminine form escolieres is rendered as banāt al-kuttāb. ${ }^{49}$ European travelers to the Ottoman Empire reported since the second half of the sixteenth century about elementary schools for girls. ${ }^{50}$ Teachers (maitre, precepteur) are rendered as mu'allim, ustādh, murabbī and the Turkish lālah (sic). ${ }^{51}$ In a variant of the master he translates maitre aux arts as mullā, mu'allim, shaykh al-kuttāb and mudarris,

$45 \quad$ Ibid., p. 44, 53, 55, 58, 71, 74, 78, 96, 147, 156, 194, 206, 220-1, 267, 270, 286, 297, 544, 554, 571, 708 709, 785, 788, 798-799, 1310-1311, 1318, 1337, 1390, 1411-1415, 1547, 1551, 1556-1558, 1570-1571 et al.

46 Ibid., p. 275.

47 Ibid., p. 286.

$48 \quad$ Ibid., p. 320, 555 .

Ibid., p. 555

50 SONJA BRENTJES, « The Interest of the Republic of Letters in the Middle East, 1550-1700 », Science in Context, 12/3 (1999), p. 435-468.

51 Ibid., p. 1017, 1348; the term is of Turkoman origin; see CLIFFORD EDMUND BOSWORTH, « Lālā », in PERI J. BEARMAN et al. (eds.), Encyclopaedia od Islam, New Edition, vol. XII, Supplement, Brill, Leiden 2004, p. 547. 
equalizing thus the different terms on the level of the kind of knowledge, which they teach. On the institutional level, however, he ranks these terms differently. He identifies, for instance, the madrasa not only as a school, but also as an academy. Hence, he translates mudarris also as academicien as well as professeur. ${ }^{52}$

More revealing about the familiarity of the dictionary's compiler with the customs inside the madrasa than the mere names of the two kinds of schools and their teachers is the set of correspondences that he provides for words like débat, debatre ou disputer, disputte, dissertation..$^{53} \mathrm{He}$ listed as members of their semantic field in Arabic munāzara, bahth, mubāhatha, jadal, mujādala, munāza'a, munāqara, musājara (sic, mushājara) and mushātama. Under the entry débat he attributes all those activities and disciplines to the madrasa: « kamā tajrī fi l-madāris » (as they take place in the madāris). ${ }^{54}$

The amusing aspect of the list of Arabic terms is that Pétis de la Croix clearly understood the ad hominem nature of many debates and controversies that madrasa teachers and other scholars engaged in, but concealed them to his French readership. While the first part of the Arabic terms except for bahth and mubāhatha also can signify highly offensive oral encounters, the second part is outspokenly mean. The scholars bicker, quarrel, wrangle, fight or vituperate.

Pétis de la Croix non-surprisingly also learned the terminology of codices, copies, commentaries, gloses, supergloses, epitomes or quotations: șahîfa, nuskha, matn, sharh, hāshiya, tafsîr, ta lìqa, ta' wīl, khātima, tatimma, mukhtașar and mu'jiz (sic), isnād and shahāda or istishhād. ${ }^{55} \mathrm{~A}$ commentary with quotations he translates as sharh bi-qāla aqūlu (a commentary with: he said: I say). ${ }^{56}$ Since the latter is not a technical terminus, but a description of a textual mode, he probably learned it through reading philosophical or theological texts with his Muslim teachers.

In addition to names of disciplines, institutions, professions and scholarly themes, the dictionary also lists names of scholarly authorities and in a few cases designations of historical periods. Here it becomes clear that the compiler wished to help visitors of the two Islamicate empires, above all probably missionaries, to broaden the knowledge of ancient authorities among the people they encountered during their travels. There is no name of a scholar from any Islamicate society to be found in the dictionary. Nor does it contain names of early modern scholars from France, England, the Low Countries, Italy or Germany. The only scholarly authorities who appear in the book lived in antiquity and are mostly of Greek and to a small extent of Roman descent. In some cases, Arabic or Arabo-Syriac transliterations, which clearly come from local sources in the Ottoman or Safavid

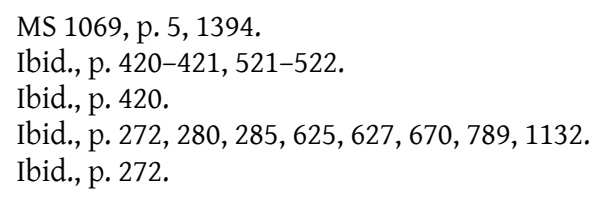


Empires, are used as for instance for Aristotle: Arisțū, Arisțātāli $\bar{s} .{ }^{57}$ In other cases, such Arabicized forms are avoided and Greek or Latin forms are transliterated as for Pliny, although the French uses the vernacular forme Pline: Bilinìy ūs. ${ }^{58}$

Let me now turn to the dictionary's scholarly content. Its vocabulary shows that in the late seventeenth century ancient and medieval theories, concepts and subjects continued to be appreciated and believed in. The new sciences are almost invisible. Aristotle's concept of the first mover, the differentiation of the soul in intelligible and sensible or of animals in rational and irrational, the theory of the four elements, the identification of meteors as "sublime exhalations of high air ", humoral pathology and astrological, divinatory and alchemical themes are explicitly represented, while the new ideas of gravitation, differential and integral mathematics, the inclined plane, heliocentrism or ellipses as planetary paths are absent. ${ }^{59}$ Even more particular expressions such corps elementaire testify to Pétis de la Croix's intellectual affiliation to late scholastic Aristotelism in Christian Europe ${ }^{60}$ Nonetheless, the new atmosphere in the sciences and the production of books in some European countries left an imprint on the dictionary's vocabulary. It talks of printing $\left(t a b^{c}\right)$, printing presses $(m a t+b \bar{u})$, journals (daftar yawmi [daily notebook, register, ledger]), ingenieurs (mușannif al-ālāt al-harbiyya wa-mi mār alhușūn [the composer of war instruments and the architect of fortresses]), innovations (bid'a) or inventions ( $i k h t i r \bar{a}^{\prime}$, ayjā d (sic, $\bar{j} \bar{j} \bar{a}$ ) [only for the second word: production, creation]). ${ }^{61}$

This small list of terms illustrates the main problems that Pétis de la Croix faced and the choices he made. Daftar yawmi intensifies the meaning that the word daftar had acquired in the early modern period as a register or ledger with daily made entries, but it certainly does not describe the newspaper, which Pétis de la Croix apparently had in mind. But since there did not yet exist newspapers in the Ottoman or Safavid Empires, his choice to specify that he meant some daily (made) booklet is the closest he could come to transfer the meaning of the new product. He made a similar choice when he described the content of the word ingenieur. He could have chosen muhandis, which was a well-established Arabic term for builders of canals, water-lifting and similar machines or architects in general. But he obviously wished to explain the French neologism ingenieur and its professional content and status to an audience in the Middle East.

Ikhtirā seems to have been a more widely spread term with the meaning of invention in the two early modern Islamicate societies, since it is found in the same interpretation in a Persian-Italian dictionary with later added Turkish and

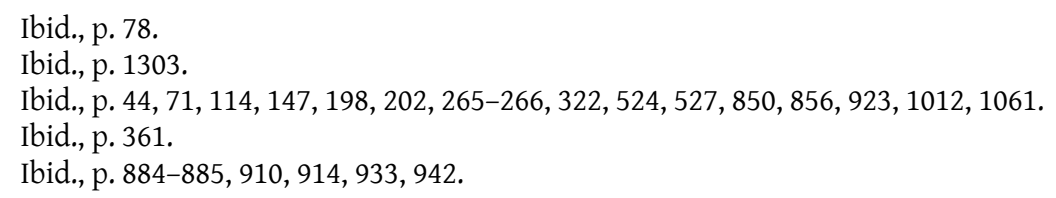


Armenian translations, in all likelihood produced by a Carmelite missionary in Isfahan before $1622 .{ }^{62} \bar{L} y \bar{a} d$, however, may have been of a more limited usage, if it is not another example of Pétis de la Croix's own identification as rendering sufficiently well the French term.

Problematic is the translation of innovation by bid' $a$ without further explanation or specification, since here a French term with by then positive connotations is identified with an Arabic term with clearly negative meaning. The Persian-Italian dictionary shows that this negative meaning was fully understood by the missionaries: inuentione mala $=$ bid'at. ${ }^{63}$ If Pétis de la Croix thought that the French invention had a negative connotation like bid'a, he either worked with a much older vocabulary, compiled in the 16th or earlier 17th centuries when indeed invention was not yet primarily considered as a positive act, or he was one of those who rejected the semantic change of the word longer than other parts of French society. A nouvelle question or a nouveau cas he translates as haditha, a word, which, while less spectacularly negatif, had also drawn critical comments from conservative corners, when the Mamluks described with it the changes they had introduced in the Meccan customs of pilgrimage. ${ }^{64}$

Mostly absent are the traditional sciences and tașawwuf (MS 1069, pp. 296, 508, $729,1572,1884)$. This is surprising not only because Pétis de la Croix spoke freely about his study of the Qur'ān, hadith and Sufi practices in his travel account, but because the knowledge of religious doctrines and beliefs was essential for diplomacy and the apostolic mission. The few terms present in the dictionary suggest moreover that the clientele of the dictionary was meant to converse primarily with Sunni Muslims. For such an interpretation speaks, for instance, the claim «tout le mahometisme roule sur le hatits (sic) », (madār al-islām 'alā lhadìth) and the absence of any clear Shî̀ pronouncement (MS 1069, p. 1572).

\section{Religious Matters}

The vocabulary on educational and intellectual matters of the anonymous dictionary favors Muslim institutions and traditions. This differs when religious matters are concerned. Here, it is clearly the French user of the dictionary whose upbringing, beliefs and expectations are privileged. New Catholic institutions like the Propaganda Fide, new communal developments among Christians in France, the Low Countries und German lands like Lutherans or Huguenots are mentioned and conversion is taken to mean exclusively conversion to Catholicism, although the Arab speaker would not always understand this point with certainty. ${ }^{65} \mathrm{~A}$ new

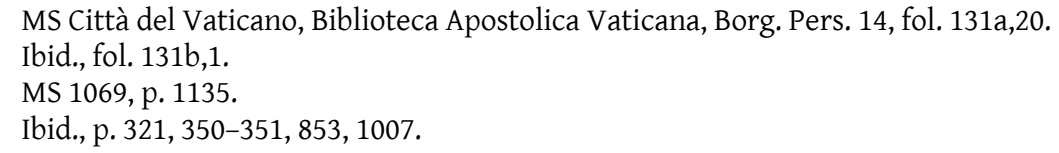


convert is, for instance, called in Arabic qarïb al-'ahd bi'l-din [having adopted recently the faith (or religion)].$^{66}$ This could be, of course, any kind of religion. This is, however, part of Pétis de la Croix's intention when speaking about religions. They are clearly not of equal standing to him. Conversion to Islam, for instance, is not seen as a choice between religions, but as a choice between people or states. ${ }^{67}$ Some of this vocabulary is presented with negative sub-tones. In numerous cases, the Arabic correspondances are either transliterations or translations produced by Pétis de la Croix himself. Although Pétis de la Croix undoubtedly also learned with Syriac Christians, their religious doctrines have no presence in the dictionary, although he mentions their language Syriac and their designation as a religious community. ${ }^{68}$ If expressions refer to Islam, it is declared to be a doctrine created by Muhammad, i.e. Mahometisme, or a false religion. ${ }^{69}$ In a few cases like the annunciation of the virgin, Muhammad's companions, the five prayers or Muhammad's flight from Mecca the correct local expressions are presented..$^{70}$ In one case, he identifies in French an Arabic term as shared by Muslims and Christians, explaining that qibla means " the place towards which one turns for praying to God; with the Christians Jerusalem; with the Mahomedans Mecca ». ${ }^{71}$ On the Arabic side, however, he adds two exclusively clearly Islamic terms, i.e. $k a^{\prime} b a$ and baytu llāhi l-harām [the Holy house of God = ka'ba]. Between the two is written baniyya, possibly a mispelling for binya, which is a much more general term than any of the other three, since it means building structure.

The Christian vocabulary includes basic Christological events like the annunciation of the virgin, apocalypse, beatitude, epiphany, eucharisty, the religious acts in human life like baptisme or apparition, religious ways of life like the anachorete or the purpose of the contemporary activities of Catholic orders in the Ottoman or Safavid Empires like the apostolat, conversion and the writing of apologies, institutions like the already mentioned Propaganda Fide or the archbishopry and important figures of different standing like God's lamb, the antichrist, the apostles, Christophles, Barabbas or Chrysosthomos. ${ }^{72}$

As in other semantic contexts, religious vocabulary is not only presented in single words, but important concepts are also narrated in form of short sentences like « Il luy apparut en forme de colombe $» .{ }^{73}$ When a Christian term does not exist for rendering an Islamic term properly, Pétis de la Croix sometimes correctly explains their significance as is the case with barzakh. Here he explains in French:

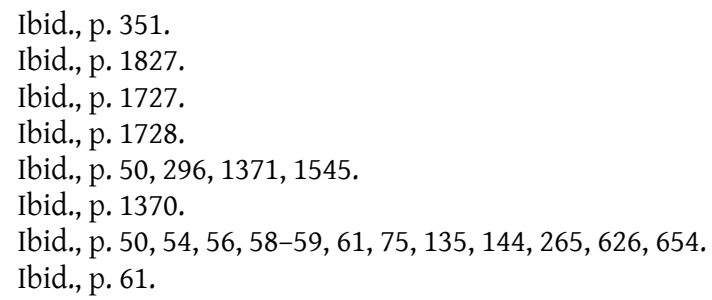


«Limbe sejour des ames depuis la mort jusquau jour du jugement selon les mahometans » [limbo, abode of the souls since the death until the day of judgment, according to the Mahomedans $].^{74}$ In cases, where the religious concepts are shared between Christianity and Islam, Pétis de la Croix provides in Arabic only the Christian description, ignoring the Islamic alternative. The French terms do not indicate this cultural reductionism. An example is ascencion, which is translated as « irtifā' sayyidinā al-masī ị ilā l-samā̄i » [the ascension of our Lord, the Messias, to the heaven]. ${ }^{75}$ In the corresponding Islamic context, the lengthy descriptive translation could be simplified to mi rāj. Since it is highly unlikely that Pétis de la Croix did not know neither the word nor the story told about it, his abstention from using Islamic terminology and providing information about Islamic concepts and stories was in all likelihood a conscious, intentional decision. Since he says in his travel account very clearly that in Iran Christians, in particular foreign visitors, could speak comparatively freely about their religious beliefs and traditions, while their Muslim hosts would reply with information on their own beliefs and traditions, this lack of Islamic religious terminology and concepts seems to underline that the dictionary's users were primarily seen to be active in Sunni Mediterranean societies. ${ }^{76}$

One of the relatively few Islamic concepts in the dictionary is ismäu (sic) llāhi lhusna [the beautiful names of God]. ${ }^{77}$ Pétis de la Croix translated the expression as les attributs de Dieu [the attributes of God]. This rendition is surprising, since it interprets the expression instead of translating it. Moreover, it limits the rich discussions of divine attributes to the concept of God's 99 names. ${ }^{78}$ But a look into Pétis de la Croix's Arabic-Latin dictionary shows that he indeed believed the two translations to be valid. This is one of the instances referred to at the beginning that link the two dictionaries with each other. Vocalizing the expression in the same manner as in M 1069, he rendered it in Latin as 99 nomina sancta seu attributa $\operatorname{dei}^{79}$

Another Islamic concept given in MS 1069, which was important for polite behavior, is the wish that God may have mercy upon an interlocutor and the proper answer to such a wish, namely " may God recompense you ». ${ }^{80}$

Pétis de la Croix registered even less terms about Jews and their beliefs and practices than those referring to Islamic matters. They are historico-geographical terms like Galilee or Judea, the name of the religion and its practioners together

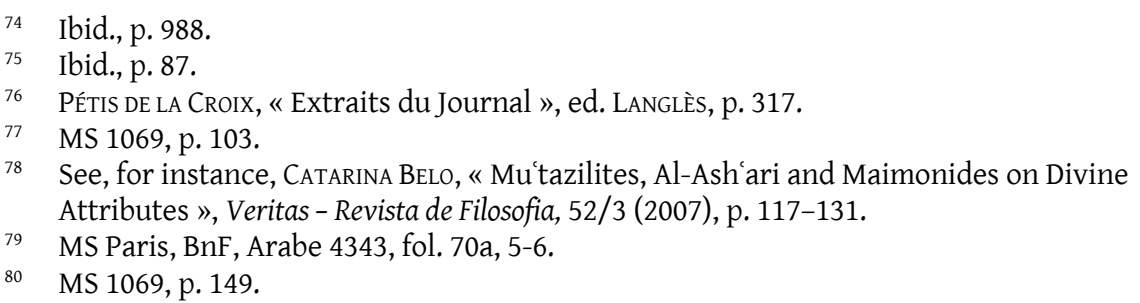


with Judas Iscariot. ${ }^{81}$ This meagre set of terms seems to be chosen because of their relevance for Christian history. Negative religious terms Pétis de la Croix wanted his readers to learn are apostate, atheist, blasphemateur, blaspheme, la crusade contre les infidels, heretique, idolatrie, schismatique. ${ }^{82}$ In his phrase on conversion he indicates one of the reasons why one has to know such words: to separate the good from the bad peas as in Cinderella's tale. Conversion to the Catholic religion meant to him «al-rujū' 'an al-raf̣̣ wa'l-dukhūl fī l-dīn al-qātūlīqī » [revocation of disavowal and entrance into the Catholic faith]..$^{83}$ The first half phrase carries, however, two further connotations. If « al-rujū 'an al-rafd » is read or heard in a context of early modern conversions from Catholicism (or Protestantism) to Islam, it could mean that Pétis de la Croix thought here of the return from being a renegade. If it is, however, read or heard in the context of inter-Islamic communal strife it could signify a return from or disavowal of Shîi Islam. This ambiguity may suggest that Pétis de la Croix learned such a phrase while in Aleppo, but certainly not in Isfahan, if it is not simply another case of his own efforts to describe what for him conversion to Catholicism meant.

\section{Politics, Navigation, Crafts and Commerce}

A very attractive aspect of Pétis de la Croix's dictionary is the remarkable number of words and compounds about navigation, war, captives, piracy, the crafts, diseases, plants, animals, alchemy and commerce. The dictionary clearly has one leg strongly anchored in the realities of life and diplomacy of the late seventeenth and early eighteenth century. It is not limited to elite knowledge cultures, religions and traveling. This quantitative presence of lived realities and the broad scope of its terminology leaves little doubt that one of the dictionary's functions was to provide future secretaries and interpreters of French ambassadors with the needed knowledge to talk about capitulations, the freeing of captives, arms and the treatment of diseases. Although no statistics is available for the dictionary since there does not exist yet a digitized form of it, the many terms for ships, anchors, pilots, cannons, bombs, guns, gunners, the arsenal, ports, troops, the leftovers of a battle, the compass, maps, admirals, sailors, corsairs, pirates, captives, ransom or bullets are amazing. ${ }^{84}$ As other words of the dictionary, they reflect the culturally mixed activities on all levels of confrontation and cooperation in the Mediterranean, since they point to military as well as peaceful undertakings and use genuine Arabic words as well as transliterations of mostly

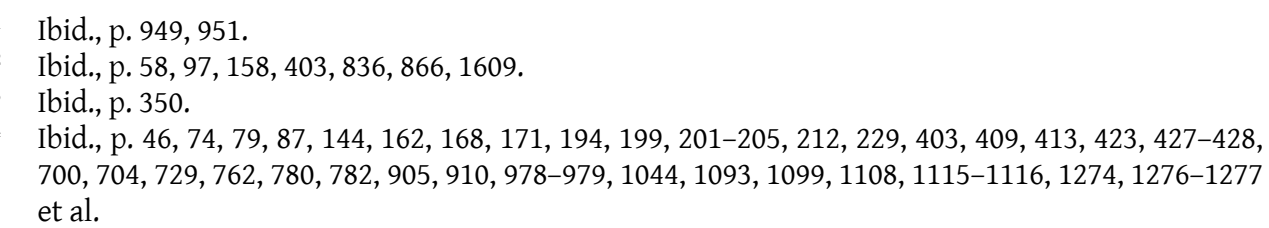


Italian words. They are listed alone, side a side or together with each other. They also contain asymmetries as other word clusters in the dictionary, which either point to misunderstandings or shifts in semantic fields of older words. An example is the identification of khanjar, which still means dagger, as a bayonet. ${ }^{85}$ The perhaps most interesting of the phrases connected to this word cluster is Pétis de la Croix's statement that money is the nerve of war. ${ }^{86}$ Any Middle Eastern interlocutor would have missed his point, however, since the translations listed on the right side of the phrase say: marāt (sic) al-jihād [times of jihad]; al-māl lā mulkillā bi-rijāl [financial property only becomes supreme authority with men]; lā rijāl illā bi'l-māl [no men without financial property]. ${ }^{87}$

Among the vocabulary for the crafts, craftsmen and produce like clockmakers, goldsmiths or builders, the words and expressions around the balance are particularly visible, since they appear more often and in greater variety than any of the other terms. Not only do the basic terms for the equal- and unequal-armed balances appear, i.e. mizān and qabbān. ${ }^{88}$ Pétis de la Croix also collected translations for the scales, the beam, the tongue, the counterweights, the people using such balances and a courtly office for balances. ${ }^{89}$ The head of the office was the qabbanni. ${ }^{90}$ Some people with such nisbas have left texts behind, which are more than lists of weights, but deal with the theory of the balance. A search for the office in Arabic sources suggests that it already existed before and parallel to its use in the Ottoman realm. The fifteenth-century Meccan historian Ibn Fahd reported about various officials, among them the mashhüd al-qabbān (the one who witness the steelyards, weightmaster?), who imposed non-Islamic taxes on merchants. ${ }^{91}$ Stilt collected a few references to the qabbāni from Ibn al-Ukhuwa (d. 1329) and alMaqrīzi (1364-1442). They indicate that the task of such a person was to go to the market place with a steelyard and weigh for buyers and sellers. ${ }^{92}$ No comprehensive history of the office exists, however, for any of the Middle Eastern dynasties.

\section{Cultural Boundaries}

Cultural boundaries reflect the distances between social, economic and political structures and modes of living in different societies, here France, the Ottoman and

$35 \quad$ Ibid., p. 144.

86 Ibid., p. 1121.

87 Ibid., p. 1121.

88 Ibid., p. 131, 1261.

Ibid., p. 131, 140, 719, 964, 1261.

90 Ibid., p. 1261.

91 John Meloy, « Imperial Strategy and Political Exigency: The Red Sea Spice Trade and the Mamluk Sultanate in the Fifteenth Century ", Journal of the American Oriental Society, 1231 (2003), p. 5.

92 KRISTEN STILT, Islamic Law in Action: Authority, Discretion, and Everyday Experiences in Mamluk Egypt, Oxford University Press, Oxford 2011, p. 137-139. 
the Safavid Empire. When trying to render them comprehensible in a different language, one can opt for a cultural or a philological identification of the different items or one can try to explain their meaning to the other side. A cultural translation identifies one item here with an item there, like academy with madrasa. It also can translate a cultural identification of an item in its home culture rather than the item itself, like Christophle as the carrier of Christ. Philological rendition can also follow two different approaches. One is transliteration, where the foreign word is transliterated either according to its written or its spoken form. The other is the literal translation of its components. When meaning is explained, like in the case of Islamic religious matters, such explanations show the degree of familiarity of the dictionary's compiler with the beliefs, customs, instutions or structures of the foreign society as well as the willingness to recognize and respect difference.

Pétis de la Croix used all of these strategies in his dictionary when creating equivalences. Not all transliterations are, however, his invention. Several rather reflect the longstanding cultural mix and interdependence in and around the Mediterranean up to the Caspian Sea between Christian and Islamicate societies and their peoples. Literal translations of either the French or the Arabic terms can be found repeatedly. In some cases, Pétis de la Croix identified French institutions, customs or rituals with specific institutions, customs or rituals of the Ottoman and Safavid Empires. Most of them belonged to Muslim cultural spaces, but some also were borrowed from Christian communities. Finally, he identified terms from older Arabic literature with phenomena either from intellectual history in ancient or Latin Europe or from contemporary Ottoman and French politics and social stratification or geography at large.

Several such crossings of boundaries were quite successful and provided both reader and listener of the vocabulary with the chance to comprehend the other's meaning. In other cases, Pétis de la Croix's choices will have seriously misled an interlocutor in an Islamicate society. Examples of successful cultural translation are baqlava as almond pastry, anachorite as habis [hermite], apoticaire as sharābāt<j>i [the producer and/or seller of syrups], canonical as shar'ī, or Chaldea as 'irāq al-'arab or 'arabī [the Arabic Iraq]. ${ }^{93}$ Misleading are Pétis de la Croix's renderings of academy as madrasa, tradition of the ancients as manqūlat al-salaf [transmitted from the forefathers], antarctic and arctic as southern and northern, authority as isnād, which is a chain of transmitters of sayings of the Prophet or of other information, of Babilon not only as bābil, but also as Baghdad, charlatan as liar, comedy as lu'bu (sic) taqlidin [a play of imitation]. ${ }^{94}$ Babylon and Baghdad are located at different coordinates in Iraq, but European writers, travelers and readers believed against

\footnotetext{
MS 1069, p. 41, 50, 59, 199, 229.

Ibid., p. 5, 51, 56, 76, 122, 127, 243, 289.
} 
better evidence well into the eighteenth century that this was not the case. Their desire to translate the Islamicate world into the geography and history of Greek antiquity overtook their willingness to trust eyewitnesses to the contrary like Pietro della Valle. The translation of comedy as « a play of imitation » tries hard to render a certain aspect of the show, but misses out in the sense that la $b$ or li'b means rather a game with balls, swords or horses, to name only a few examples, than a play on a stage. Even worse is Pétis de la Croix's decision to take taqlid as the compound's second element, since this word would have first and foremost reminded a Muslim interlocutor of his legal duty to follow the interpretations of the law and other religious commandments by a mujtahid or renovator of Islam in any given century.

Depending on the mood of the listener to the following failed identifications, he might either become exasperated or shake his head in amazement about the incomprehensible information provided by his foreign guest. Pétis de la Croix's dictionary namely teaches that Mount Caucasus is Mount Qāf, the mythical mountain of the Qur'ān, which encompasses the earth, and that a censor is somebody who either bickers, getting in an argument or a denier. ${ }^{95}$ The first failed identification might actually be the result of a mistake by the copyist, since the Caucasus is Qafqāz. The second identification had to fail, since there was no institution like censorship in Islamicate societies. The choice of Arabic expressions for such an unknown institution may, however, reflect Pétis de la Croix's own exasperation with its interferences in his life as an author.

Differences in the scholarly development during the sixteenth and seventeenth centuries between France and other Catholic or Protestan countries in Europe and Islamicate societies become also visible in Pétis de la Croix's efforts to build bridges. The word cosmography in the sense of geography did not exist and mathematical geography or geodesy had become a part of 'ilm al-hay'a. Pétis de la Croix chose to ignore this disciplinary difference and translated cosmography as rasm al-dunyā [drawing of the world], qiyās al-ard bi'l-handasa [measurement of the earth with geometry] and ma'rifat al-kürat (sic) bi-'ilm al-handasa [knowledge of the sphere with geometry]. The profession of a cosmographer did not exist at all. Nonetheless, Pétis de la Croix identifies such a person as rāsim al-dunyā [the draftsman of the world]..$^{96}$ An interesting choice, oscillating between Arabic and French concepts of curiosity in the seventeenth century, is the translation of curious with lover of rare things (or: gifts) and curiosity with love of details. ${ }^{97}$ In Arabic, tuhfa combines as its meanings gift, curiosity and rarity among other things, but not details. The love of details, on the other hand, is one of the aspects that defined the

$\quad$ Ibid., p. 212, 219.

96 Ibid., p. 365.

97 Ibid., p. 413. 
newly found appreciation of curiosity in early modern Christian Europe, including France.

Between these two extremes there are translations that miss somehow the right point, although they are close to the intended meaning, or that impose a particular view, held by Pétis de la Croix, on an existing Arabic term. The type of almost correct cross-cultural renderings include simple mistakes in explanatory translations like the translation of antipodes as people who live below the earth, the reduction of a large field of meaning on the side of the French term by much more limited concepts as the translation of apparition as dreams and the effort to find some term used in Islamic scholarly culture for a historical period that they neither named nor considered of particular value to their own cultural identity as in the case of antiquity, which Pétis de la Croix first renders as the old and then by the ancient philosophers. ${ }^{98}$

Finally, there are translations where it is not clear, which kind of transformation took place to produce the registered results. In two cases, for example, I could determine the language into which Pétis de la Croix translated only with the help of colleagues: strawberry (fraise) and raspberry (framboise). ${ }^{99}$ The former is rendered in the dictionary as qūja bimishi and the latter as jilk. ${ }^{100}$ Allowing for errors with regard to the diacritical points and including the deviations between Arabic forms of Turkish words and the latters spoken forms, qujja bimishi is most likely koca yemiş, while jilk renders çilek. Spelling errors are not the only issues here, however. At stake is also the history of fruit names. Today, koca yemiș stands for the reddish, globular fruits of the Arbutus unedo L. and çilek for strawberry. According to nineteenth- and early twentieth-century Turkish dictionaries, this was not always the case. The two terms could also signify other fruits. According to Semseddin Sami, koca yemis grows in the mountains and is similar to çilek. ${ }^{101}$ Redhouse identified raspberry as agaç çilegi, commenting that it was a «strawberry that grows on a tree $» .^{102}$ Pétis de la Croix's dictionary might well reflect a similar linguistic and botanical situation for the late seventeenth century.

\section{Conclusions}

I hope to have provided sufficiently plausible arguments for my belief that the ancestor of the anonymous dictionary was in all likelihood compiled by François Pétis de la Croix between 1680 and 1713. I also hope to have shown that it is a

8 MS 1069, 57, 58, 61

99 I thank Feza Günergun, Istanbul, Evrim Binbaşı, Bonn and Maria Pia Pedani, Venice.

100 MS 1069, 747.

101 ŞEMSEDDIN SAmi, Kamus-i Türkî, Ikdam Matbaasi, Dersaadet 1317 (1901-1902), p. 1090.

102 James William Redhouse, English and Turkish Dictionary, pt. II: Turkish-English, Bernard Quaritch, London 1857, p.638. 
unique product, full of impressive knowledge, insights, efforts of good will and cultural limitations. It was as much an offer to understand the people with whom a learner of the words, expressions and phrases of this dictionary might eventually converse as it was a chance to inform such potential intelocutors about political, social, cultural, religious, material and natural things of major interest to Pétis de la Croix and his contemporaries in France. The preference for Sunni interlocutors shines through a number of choices Pétis de la Croix made when deciding which words to include and how to render them. This is not surprising. The Ottoman Empire and the North African states of Tripoli, Tunis, Algiers and Morocco were the primary political partners of France in the late sevententh century.

The dictionary shows that it was possible for a seventeenth-century young Frenchman to acquire an intimate knowledg of the intellectual worlds of the Ottoman and Safavid Empires, even when he did not manage to cross all the cultural boundaries set by his upbringing in Paris. Muslim scholars in Aleppo and Isfahan accepted him as a student and taught him as if he were one of their more ordinary Muslim charges. It was the intellectual generosity of those teachers that transformed Pétis de la Croix into the most successful interpreter of the French court and gave him skills that were recognized and appreciated both by the French crown and its Muslim counterparts in North Africa and Istanbul.

The dictionary lives through the thus acquired amazing knowledge of the scholarly worlds of the Ottoman and Safavid Empires, its at times witty and at times critical ditties about scholars, wars and daily life as well as its cultural, intellectual and personal limitations to a one-sided recognition of Catholicism as the only true religion, an overwhelming focus on scientific content widely outdated in the late seventeenth or early eighteenth centuries and not clearly situated within Muslim scholarship. The dictionary leaves no doubt about Pétis de la Croix's particular familiarity with astronomy as practiced at the madrasa in form of a dominantly textual knowledge. But it also reveals minor traces of lateAristotelian debates in Catholic and Protestant Europe, while being widely innocent of any of the new concepts, ideas and methods. The only inkling that this might not fully be a correct reflection of Pétis de la Croix's knowledge is the rendition of curiosity as love for detail, since this was a new rhetoric of knowledge and responsibility for the higher good during the first half of the seventeenth century. But it was mostly out of fashion by the end of that time.

The fact that this copy is not an autograph, but a product of someone else and the realm of readers, who actively corrected and annotated the work of the compiler, prevents a full understanding of which of the deviations and mistakes are the results of Pétis de la Coirx's work and which slipped in at a later stage. But the fact alone that the dictionary had been used, cross-referenced in its ancestor and with other knowledge products shows that the dictionary did not live as a 
lonely inhabitant of a dusty shelf. It had a life of its own. Too bad it cannot tell us who its users were and what they did with the newly acquired knowledge.

\section{Bibliography}

Manuscripts

MS Paris, BnF, Arabe 1473.

MS Paris, BnF, Arabe 1683.

MS Paris, BnF, Arabe 4343.

MS Paris, Missions Étrangères, 1069.

MS Città del Vaticano, Biblioteca Apostolica Vaticana, Borg. Pers. 14.

Texts and Studies

Ageron, Pierre, Mustapha Jaouhari, «Le programme pédagogique d'un arabisant du Collège royal, François Pétis de La Croix (1653-1713) », Arabica, 61 (2014), p. 396453.

Belo, Catarina, "Mu'tazilites, Al-Ash'ari and Maimonides on Divine Attributes », Veritas - Revista de Filosofia, 52/3 (2007), p. 117-131.

Bosworth, Clifford Edmund, «Lālā », in Peri J. Bearman et al. (eds.), Encyclopaedia od Islam, New Edition, vol. XII, Supplement, Brill, Leiden 2004, p. 547.

Brentjes, Sonja, « The Interest of the Republic of Letters in the Middle East, 1550$1700 »$, Science in Context, 12/3 (1999), p. 435-468.

- «MS or. fol. 100. Adam Olearius' and Haq Virdī's (c. 1584-1650) Persian-Latin Dictionary ", in Kirsten Baumann, Constanze Köster, Uta Kuhl (eds.), Adam Olearius - Neugier als Methode. Tagungsband zur Internationalen Tagung 'Der Gottorfer Hofgelehrte Adam Olearius. Neugier als Methode?' Schloss Gottorf, Schleswig, 2427. Juni 2015, Michael Imhof, Petersberg 2017, p. 144-151.

Galland, Antoine, Journal d'Antoine Galland pendant son séjour à Constantinople, 16721673, ed. by Charles Schefer, Leroux, Paris 1871 (reprint Kessinger Publishing, LLC, Whitefish, MZ 2009; Cambridge University Press, Cambridge 2012).

- Le Journal D'Antoine Galland (1646-1715): La Periode Parisienne (1712-1713), 3 vols., ed. by Frédéric Bauden et al., Peeters Publishers, Leuven 2011-2015 (Association pour la promotion de l'histoire et de l'archeologie orientales. Mémoires, 6-9). 
Günergun, Feza, «Travellers in the Field: Conveying Botanical Material from Ottoman Turkey to Western Europe (16th and 17th c.) », unpublished.

Lane, Edward William, An Arabic-English Lexicon, 8 parts, Librairie du Liban, Beirut 1968.

Meloy, John, «Imperial Strategy and Political Exigency: The Red Sea Spice Trade and the Mamluk Sultanate in the Fifteenth Century ", Journal of the American Oriental Society, 1231 (2003), p. 1-19.

Moreri, Louis, Supplement au grand dictionnaire historique, genealogique, geographique, \&c., vol. II, La Veuve Lemercier et. al., Paris 1732.

al-Muhibbī, Muhammad, Tārīkh khulāșat al-athar fí a'yān al-qarn al-ḥādī 'ashar, alMațba'a al-Mișriyya al-Waḥbiyya, Būlāq 1284/1867.

Pedani, Maria Pia, La grande cucina ottomana. Una storia di gusto e di cultura, Il Mulino, Bologna 2012 (Intersezioni, 395).

Pétis de la Croix, François, «Extraits du Journal du Sieur Fr. Petits fils, professeur en arabe, ... », ed. by M. Langlès, Magasin encyclopédique ou Journal des Sciences, des Lettres et des Arts, 5 (1808), p. 277-376.

Nishio, Tsetsuo, « Un document inédit à propos des ouvrages de François Pétis de la Croix (1653-1713) », Bulletin of the National Museum of Ethnology, 42/4 (2018), 411433.

Redhouse, James William, English and Turkish Dictionary, part. II: Turkish-English, Bernard Quaritch, London 1857.

Sami, Şemseddin, Kamus-i Türkî, Ikdam Matbaasi, Dersaadet 1317 (1901-1902).

Sebag, Paul, «Sur deux orientalistes français du XVIIe siècle: F. Petis de la Croix et le sieur de la Croix », Revue de l'Occident musulman et de la Méditerranée, 25 (1978), p. 89-117.

Steingass, Franz Joseph, A Comprehensive Persian-English Dictionary, Including the Arabic Words and Phrases to Be Met with in Persian Literature, Routledge \& K. Paul, London 1892.

Stilt, Kristen, Islamic Law in Action: Authority, Discretion, and Everyday Experiences in Mamluk Egypt, Oxford University Press, Oxford 2011.

URL

http://www.perseus.tufts.edu

https://www.dictionnaire-academie.fr 